\title{
Exhibition Review
}

\section{Présence Commune, Museum Mohammed VI for Modern and Contemporary Arts (MMVI), Rabat, Morocco, 28.03.2017 - 31.09.2017.}

Présence Commune (Common Presence) was held at Museum Mohammed VI for Modern and Contemporary Arts (MMVI) as part of a wider cultural programme and festival that celebrated Africa in the Moroccan capital for seven months. It was held under royal patronage and was funded by the National Foundation of Museums (NFM).

This exhibition is yet another artistic and cultural event that materializes the kingdom's new political agenda in which cultural diplomacy is now essential. Morocco's new cultural agenda aims to transform national museums into modern inclusive spaces that democratize access to culture in cosmopolitan Morocco and celebrate the plurality of Moroccan society. In this cause, Présence Commune came to celebrate African cultural diversity in the Moroccan capital. Mehdi Qotbi, president of the NFM, stated that 'Moroccan Museums are to highlight the richness and diversity of the Moroccan culture. Morocco has a plural identity; it is Amazigh, Arab, Mediterranean, African, Muslim, and Jewish at the same time' (Qotbi 2013, trans. Bahji 2017). This event was also programmed to celebrate Morocco's return to the African Union in 2017.

The inauguration of MMVI in 2014 was an unprecedented cultural event and a major step forward in the country's new cultural agenda. MMVI is the first national art museum in Morocco. Since gaining independence in 1956, the Moroccan cultural landscape has lacked a national public art museum to preserve and display national arts. Thanks to the NFM, the new museum came to change the situation. MMVI was created to collect, preserve, celebrate and introduce national modern and contemporary arts to local and international audiences. The museum aims to introduce the local public to international arts by holding temporary exhibitions of international artists, such as Giacometti, Baldaccini and Picasso. MMVI has also been designed to achieve specific goals in postcolonial modern Morocco. It dedicates its underground galleries to temporary workshops and participatory activities by Moroccan and international postmodern artists. MMVI also strives to serve the local community by democratizing access to culture. It aims to function as a democratic public space that initiates intercultural dialogue and promotes tolerance in a globalized world. MMVI acknowledges and includes the various cultural and artistic products of a plural society. This is critical in a post-colonial North African, Mediterranean, Amazigh, Arab, Muslim and Jewish country that aims to be immune to all forms of cultural, ethnic and sectarian conflicts amid the challenging security situation of the region.

In three exhibition spaces, Présence Commune brought together an eclectic collection of contemporary artworks by a number of renowned African artists. Paintings, photographs and sculptures were displayed together in an exceptional visual dialogue under the following themes: return to the origins, African identities, globalization, intercultural exchange and ancestral traditions. This dialogue prompted subtle visual comparisons among the works and added meaning and value to the content. It tied the works in a narrative by means of both artistic style and content, and highlighted form to reflect and make reference to a variety of universal cultural and artistic influences. The exhibition represented a microcosm of African societies through the universal language of art. The artworks were grouped together by similarities of subject matter or formal qualities to guide the viewers to discover the cultural métissage ${ }^{1}$ (weaving) of these societies and witness their openness to other civilizations through art, a language of creative and harmonious interaction. 
This review will contextualize and analyze the exhibition and examine the communicative strategies it used to convey its messages. The review will show that the concept of cultural metissage, which predominated in this exhibition, was emphasized through both artistic media and content to create a liminal space where hybrid identities and cultures would meet, interact with one another and negotiate issues of cultural diversity, postcoloniality, modernity, tradition and globalization in today's Africa.

Museums that represent and examine multiculturalism in their own societies cannot escape the issues of representation inherent in exhibiting cultures (Karp 1991: 378). The challenges this exhibition faced were related to both representing cultural diversity in a number of postcolonial societies and discussing issues of modernity and globalization. Curated by the participant artists, Présence Commune aimed at meeting these challenges through the use of specific concepts, communication techniques and exhibition design.

The introductory labels, written in Arabic and French, invited the viewers to discover the diversity of today's African cultures. The labels stated that present Africa is ancestral, tribal, traditional and yet modern. It was on the threshold of a new phase where identities and cultures were constantly reconstructed and renewed. Words like 'trans-cultural', 'hybrid' and 'diverse' predominated in the labels. Through raising open-ended issues and inviting reflection, the labels opened up a space for communication and constructive dialogue where the viewers could take an active role (Hooper-Greenhill 1999; Witcomb 2003).

The first gallery was dedicated to a series of clair-obscurphotographs entitled Renaissance (2014) by the Tunisian artist Wahib Chahata (born 1968) and a series of street art-inspired canvases entitled The Warrior of the Republic (2016) by the Franco-Congolese painter Kouka (born 1981). The works of both artists, displayed in a large and dimly-lit exhibition space that perfectly suited their sober tone, created a stunning dialogue between their style and subject matter. Both series depicted fascinating philosophical and mythical scenes of African people in monochromatic representations. Portraits of warriors, shamans and tribal ancestors combined the traditional and the local with the modern and the Occidental. For example, in their works, the artists borrowed artistic techniques from Renaissance art, such as portraiture, to represent their models and convey their artistic messages. The works depicted religious and symbolic scenes that made references to Greek mythology, creating a rich pastiche of art techniques and subject matter. Contemplating these unusual combinations, the viewer could sense the cultural and artistic plurality that this exhibition strived to create.

The second gallery, Memorial, paid homage to three deceased African artists. The works of two Moroccan photographers, LeilaAlaoui (1982-2016) and Othman Dilami (1986-2016), and the works of their Malian counterpart, Malick Sidibe (1936-2016), invited the viewers to discover a rich and varied artistic-documentary representation of the African people. In a formal and brightly-lit exhibition space, the photographs of the three artists represented ordinary Moroccan and Malian people in everyday life situations. Women and men from diverse ethnicities, dressed in traditional or modern clothes, posed to gaze back at the viewers, representing the self and the 'Other', at the same time. This liminal space of encounter between various cultures and artistic influences aimed at creating a double critique ${ }^{2}$ position (third-way critique) that transcended the dualities of the self and the 'Other', the Orient and the Occident and tradition and modernity. It aimed at suggesting new ways of looking and shaping new experiences and ways of thinking that the Moroccan postcolonial sociologist and philosopher Abdelkebir Khatibi referred to as une pensee autre ${ }^{3}$ (thinking otherwise) in his writings on identity and Postcolonialism.

Through grouping the three photographic series, Les Marocains (2012), (The Moroccans), by Alaoui, Les Musiciens de la Transe (2015), (The Musicians of Trance), by Dilami and Reportages Maliens (1960s), (Malian Documentaries), by Sidibe, the exhibition not only focused on the artistic techniques in these works, which combined the art of photography with the documentary, but also reflected the diversity of African societies and identities, as seen by African people themselves. Also, through the combination of the straightforward-accurate with the artistic-philosophical, this exhibition went beyond the mere act of description and invited the viewers to contemplate and rediscover the ordinary and the 'real' from a different perspective.

Capturing modernity and globalization in African societies was also discussed in this exhibition. Modernity and globalization were looked at from a different prism that transcended the constraints of dualities and superimposed discourses. The exhibition offered a look at one's 
self and represented other cultures within a postcolonial context, which most African countries shared. Similar to the concept of museums as 'contact zones' for colonial encounters (Clifford 1997: 192), a postcolonial encounter took a Khatibian third-way critique position to look at the whole picture of today's African diversity. By taking a third-way critique, the exhibition invited the viewers to be critical and subtly opened a space of discussion and understanding where it strived to decentralize hegemonic discourses associated with modernity and globalization. The point was to problematize the discursive hierarchies associated with modernity and globalization and negotiate and understand these two forces of change as integral parts of today's Africa. Here, the exhibition could be described as a 'heterotopia' where relations and differences were suspended, reversed and contested (Foucault 1998: 237-44).

The third gallery, Regard Contemporain sur L'art Africain, (A Contemporary Look at African Art), displayed a set of contemporary paintings of African postmodern artists. In a formal and well-lit space, self-referential paintings, which highlighted the practice of painting as a Western form of artistic expression, combined traditional popular motifs of ancestral African tribes with Western modern art techniques to visually narrate interesting stories. By emphasizing the artistic technique used by the artists, such as references to Occidental culture and mythology, the exhibition aimed to transform the space of display into a space of visual intertextuality. In other words, it became a space of creation where different and diverse art styles, ideas, allusions, references, symbols and signs met, influenced one another and were transformed to create new possibilities and meanings.

The works also highlighted issues of traditional collective memory, identity, duality, multiculturalism and origins in a globalized world where artistic creation is a substantial human need and form of self-expression that initiates dialogues among the peoples of the world. Contemplating the eclectic collections in this gallery, the viewers might empathize with these people as they discovered their concerns, dreams, fears, hopes, needs, aspirations and desires expressed through art. Diverse issues such as water scarcity, child education, beauty standards, fashion and health, were addressed in these works of art through which artists opened up to the audiences and shared their concerns.

The display strategies of the exhibition guided the viewers to focus on ideas of cultural metissage and multiculturalism. Cultural differences were not emphasized by means of exoticizing display strategies (Karp 1991: 379). Rather, the exhibition invited the viewers to objectively question, discuss and reconstruct the idea of the 'real'. Focus on art and artistic creation as a human need and form of self-expression established ties among these cultures.

In Présence Commune, the artistic dialogue not only tried to break barriers between the peoples of a continent, question and transcend the duality of African identity as marked by the colonial experience, and show openness to a globalized modern world: it also strived to popularize art and democratize culture; it transcended the interior space of the museum to connect with the outside world. The exhibition extended outside of the museum institution through murals, wall paintings and garden sculptures, merging with the city and trying to reach more possible audiences. This was an example of the 'outreach programmes' (Lord 2002: 315 ) and engaging activities that some contemporary museums around the globe practice to encourage the participation of larger segments of the population (Simon 2010).

Through minimal design, the exhibition clearly conveyed its messages. However, including a vivid performative exhibition or a video projection in the three galleries could have made the exhibition tremendously rich in terms of scenographic rendering. Engaging scenographic settings could have added interesting visual qualities to the exhibition. They would have added an immersive mood to the settings and brought these works to life.

Zineb Bahji

Ibn Tofail University, Kenitra, Morocco

\section{Notes}

1 Metissage culturel(cultural weaving) is a concept promoted by the Moroccan sociologist and philosopher Abdelkebir Khatibi (1938-2009) in his work Le Metissage Culturel, Manifeste (1990) and in his cultural theories on postcolonial societies. The concept is based on the idea that identity and culture are not fixed and rigid. Identity is in the process of becoming; it 
is flexible, and it owns energy for renewal. In his studies on Moroccan postcolonial identity, he focused on the cultural and linguistic hybridity of postcolonial Moroccan society and developed a number of related theories and concepts.

2 Double-critique (third-way critique/ double criticism) is a concept developed by Khatibi in his work Maghreb Pluriel (1983). This postcolonial concept draws from the postmodern philosophy of decentralization of hegemonic discourses. According to Khatibi, postcolonial writers should take a third-way critique position that transcends the dialectics and dualities inherent in colonial and postcolonial discourses. They should take an emancipatory position that sets itself free from ethnocentric writings in order to criticize and question both the knowledge systems produced within their own culture and those developed within imperial discourses. This stance aims at understanding and negotiating concepts instead of rejecting them based on their source of origin.

3 Pensee-autre (thinking otherwise) refers to the new ways of seeing and thinking that the third-way critique method yields. This concept, which Khatibi developed in Maghreb Pluriel (1983), produces new experiences and modes of thinking that build upon and transcend the absolute dualities of West/East and their binary discourses and meta-discourses on the 'Self' and 'Other'. See more in Khatibi A. (1983) Maghreb Pluriel, Rabat; Paris: Editions Denoël, 48.

\section{References}

Clifford, J. (1997) Routes: Travel and Translation in the Late Twentieth Century, Cambridge: Harvard University Press.

Foucault, M. (1998) 'Of Other Spaces: Utopias and Heterotopias', translated by J. Miskowiec, in Nicholas Mirzoeff (ed) The Visual Culture Reader, 237-44, London: Routledge.

Hooper-Greenhill, E. (1999) The Educational Role of the Museum, London; New York: Routledge.

Karp, I. (ed) (1991) Exhibiting Cultures: the Poetics and Politics of Museum Display, Washington D.C.: Smithsonian Institution Press.

Khatibi, A. (1983) Maghreb Pluriel, Rabat; Paris: Editions Denoël.

Khatibi, A. (1990) Le Métissage Culturel, Manifeste, Casablanca: Al Asa-Okad.

Lord, B. (ed) (2002) The Manual of Museum Exhibitions, Walnut Creek, California: Alta Mira Press.

Patrimoine sans Frontières (2013) 'L'évolution muséale au Maroc', 23 December. http://psf. ong/projet/fr/nos-ressources/publications/nos-regards-sur/23-regard-sur-l-evolutionmuseale-au-maroc, accessed 22 April 2017.

Simon, N. (2010) The Participatory Museum, Santa Cruz, California: MUSEUM 2.0.

Witcomb, A. (2003) Re-Imagining the Museum: Beyond the Mausoleum, London: Routledge. 